\title{
A Case of Right Pulmonary Vein Thrombosis after Left Upper Lobectomy
}

\author{
Yahya Ahmadi ${ }^{1}$, Tong Wu ${ }^{1}$, David Park ${ }^{1}$, Usama Talib ${ }^{2 *}$ and Maxwell Weinmann ${ }^{3}$ \\ ${ }^{1}$ Department of Internal Medicine, North Shore Medical Center, USA \\ ${ }^{2}$ Department of Cardiology, Harvard University, USA \\ ${ }^{3}$ Department of Critical Care Medicine, Emory University Hospital, USA
}

Submission: February 22, 2018; Published: February 26, 2018

*Corresponding author: Usama Talib, Department of Cardiology, Beth Israel Deaconess Medical Center, Harvard University Boston, MA, 02215, USA, Email: talib.usama@gmail.com

Keywords : Pulmonary Vein Thrombosis; Left Upper lobectomy

\section{Introduction}

Pulmonary vein thrombosis (PVT) is a challenging and life threatening medical condition which requires early diagnosis and appropriate management. PVT presents with nonspecific symptoms of chest pain, dyspnea, cough or hemoptysis and hence may mimic other syndromes, such as acute coronary syndrome or pulmonary embolism at initial presentation. PVT can have detrimental consequences, including right heart failure, peripheral embolism, and stroke. Common risk factors include recent history of lung transplantation, lobectomy especially left upper lung lobe resection, and malignancy. Whereas, less common risk factors include atrial fibrillation, chest wall trauma, sickle cell disease. Management of PVT is dependent upon the underlying risk factors and potential etiology, but remains a medical emergency. While PVT is usually seen in left pulmonary vein, we report a rare case of right sided PVT in a 49-year-old male diagnosed with right pulmonary vein thrombosis twelve days after left upper lung lobe resection.

\section{Case Description}

A 49-year-old gentleman with a history of type 2 diabetes mellitus, cirrhosis secondary to chronic hepatitis B, stage T2a squamous cell lung cancer undergoing left upper lobe lung lobectomy through video assisted thoracoscopic surgery (VATS) presented to the emergency room twelve days after the procedure with complaint of acute onset chest pain. The pain was pressure like, substernal, radiating to left arm and neck, 8/10 in intensity, non-pleuritic, non-positional, was noted to start at rest with no alleviating factors. Associated features included a mild headache, lightheadedness and dyspnea. Patient denied any trauma, prior history of similar complaints, diaphoresis, palpitations, orthopnea, paroxysmal nocturnal dyspnea, leg swelling, recent upper respiratory infection, fever, chills or any other medical conditions. In particular, the patient had no prior history of thromboembolic disease, atrial fibrillation or sickle cell disease. He was an active smoker with twenty pack year smoking history. On presentation to the hospital, he was hemodynamically stable with no signs of tachycardia or respiratory distress.

Initial work showed negative troponin (less than 0.03ng/ $\mathrm{ml}$ ), EKG revealed normal sinus rhythm with no signs ST-T wave changes or Q waves on the EKG. A CT angiogram of the chest was performed which revealed $1 \mathrm{~cm}$ thrombus in the stump of right pulmonary vein. Transthoracic echocardiography was then performed but did not reveal any signs of wall motion abnormality, right heart failure, tricuspid regurgitation or atrial thrombus. Patient was started on anticoagulation with Enoxaparin considering his history of underlying malignancy. His chest pain improved, with pain control and he was discharged with close follow up care with his oncologist.

\section{Discussion}

Patients undergoing partial or complete lung lobe resection are prone to develop pulmonary vein thrombosis. Left superior pulmonary vein is the most common site of thrombosis owing to its long course and propensity of stasis; although patient reported in this case was found to have a clot in the right pulmonary vein stump. Following lobectomy, the risk of pulmonary vein thrombosis is $3.6 \%$ which increases to $13.6 \%$ in those undergoing left upper lobectomy [1,2]. In 2 studies on PVT, 7 out of 193 and 5 out of 151 patients undergoing lobectomy developed left PVT [3]. In the case reported here, the patient 
developed right pulmonary vein thrombosis after left upper lobectomy. Right PVT after undergoing left upper lobectomy has not yet been reported in the literature. Management of PVT mainly depends upon the underlying etiology. In patients with PVT secondary to cancer, anticoagulation along with underlying management of malignancy is done as in the patient reported by the authors.

There is insufficient evidence to suggest the routine use of post-procedure prophylactic anticoagulation or routine imaging and echocardiography in patients undergoing lung transplant or lobectomy. Considering that the symptoms of PVT are often subtle and may have lethal consequences such as massive hemoptysis, cerebral infraction, renal infarction or systemic embolization [1,4]; routine diagnostic testing in high risk patients might not be unreasonable especially in patients with left upper lobectomy, though its utilization requires further evaluation. CT angiography of the chest is required to diagnose pulmonary vein thrombosis thrombosis along with a high level of suspicion in at risk patients. Anticoagulation is indicated in patients with PVT[4]. Further studies focusing on PVT may help us understand the disease in detail, optimize the management and prevent the high morbidity and mortality associated with this condition.

\section{References}

1. Ohtaka K, Hida Y, Kaga K, Kato T, Muto J, et al. (2013) Thrombosis in the pulmonary vein stump after left upper lobectomy as a possible cause of cerebral infarction. Ann Thorac Surg 95(6): 1924-1928.

2. Ohtaka K, Takahashi Y, Uemura S, Shoji Y, Hayama S, et al. (2014) Blood stasis may cause thrombosis in the left superior pulmonary vein stump after left upper lobectomy. J Cardiothorac Surg 9: 159.

3. Ohtaka K, Hida Y, Kaga K, Takahashi Y, Kawase H, et al. (2014) Left upper lobectomy can be a risk factor for thrombosis in the pulmonary vein stump. J Cardiothorac Surg 9: 5.

4. Ichimura H, Ozawa Y, Nishina H, Shiotani S (2014) Thrombus formation in the pulmonary vein stump after left upper lobectomy: a report of four cases. Ann Thorac Cardiovasc Surg 20 Suppl: 613-616.

\section{Your next submission with Juniper Publishers will reach you the below assets}

- Quality Editorial service

- Swift Peer Review

- Reprints availability

- E-prints Service

- Manuscript Podcast for convenient understanding

- Global attainment for your research

- Manuscript accessibility in different formats

( Pdf, E-pub, Full Text, Audio)

- Unceasing customer service

Track the below URL for one-step submission https://juniperpublishers.com/online-submission.php 